\title{
MOLECULAR CHARACTERIZATION OF PSEUDOMONAS AERUGINOSA ISOLATED FROM MILK
}

\author{
NAHLA A. ABOU EL-ROOS; EBTESAM M. MAZID; EMAN M. ZAKARY and \\ KAYRI F. ABOU EL YAZID \\ Animal Health Research Institute, Dooki, Giza, Egypt. \\ Email: (imanmagdy@yahoo.com)
}

\section{ABSTRACT}

Received at: 4/9/2013

Accepted: 26/9/2013
A total of 200 samples of raw and pasteurized milk (100 of each) were collected from supermarkets in Qaluobia Governorate and examined for prevalence and characterization of $P$. aeruginosa . The incidence of P.aeruginosa isolated from raw and pasteurized milk was $40 \%$ and $16 \%$, respectively. Serogrouping of P.aeruginosa isolated from examined samples revealed that serogroupes $\mathrm{K}, \mathrm{H}$ and, A isolated from raw milk at frequency percentage of 40, 35, and 25, respectively, while from pasteurized milk at frequency percentage of 25, 50 and 25, respectively. For the detection of the enzyme Hameolysine, Phospholipase, Caseinase and Gelatinase revaled that for serogroupe $\mathrm{K}$ it were $60,50,100$ and $90 \%$ respectively while for serogroupe $\mathrm{H}$ it were 54.5,45.5,100 and $81.8 \%$ respectively and it were $42.8,28.5,100$ and $85.7 \%$ for serogroupe A, respectively. Concerining the pathogenicity test of P.aeruginosa isolated from milk samples it was in percent 100 , 100 and 57.14 for serogroupes K, H and A, respectively. P.aeruginosa varied in its resistance to different antibacterial agents, ciprofloxacin was the most effective drug against P.aeruginosa (60.7\%), followed by enrofloxacin, norfloxacin and lomefloxacin (53.6\%). P.aeruginosa was low in susceptibility to tobromycin (25.0\%), gentamycin (21.4\%) ceftriaxone (17.9\%) streptomycin (10.7\%) erythromycin $(3.6 \%)$ tetracycline $(3.6 \%)$. The organism was completely resistant to trimethoprim, naldixic acid and doxycen. For identification of $P$. aeruginosa strains at the DNA level, Polymerase chain reaction (PCR) is used based on specific primer for $16 \mathrm{~S}$ rRNA, PCR has found to be rapid and more sensitive and specific in identification of $P$. aeruginosa, and the bands appeared at $956 \mathrm{bp}$.

Key words: Molecular characterization, P. aeruginosa, Milk.

\section{INTRODUCTION}

Milk is highly prone to contamination and can serve as an efficient vehicle for human transmission of foodborne pathogens, especially gram-negative bacteria, as these are widely distributed in the environment (Garedew et al., 2012). Such balanced diet becomes contaminated with several types of microorganisms which originate from the soil, water or skin and the hair of the animals or utensils or from the milk handlers (Lendenbach and Marshal, 2009).

Genus Pseudomonas is the most heterogonous and ecologically significant group of known bacteria, and includes Gram-negative motile aerobic rods that are wide-spread throughout nature and characterized by elevated metabolic versatility, thanks to presence of a complex enzymatic system. The nutritional requirements of Pseudomonas spp. are very simple, and the genus is found in natural habitats like soil, fresh water, and marine environments. (Aysel et al., 2012).
Pseudomonas spp. plays an important role in milk spoilage. During the storage of raw milk they produce many thermo-tolerant lipolytic and proteolytic enzymes that reduce both the quality and shelf life of processed milk (Wiedmann et al., 2000).

It is an opportunistic pathogen that can affect human, animal and birds. Amany et al., 2006). Temperature plays a major role in the diversification of microorganisms and spoilage of milk during transport, processing and storage. Psychrotrophic bacteria have been recognized as a recurring problem in the refrigerated storage and distribution of fluid milk, and perishable dairy products for several decades (Singh et al., 2012). So, the psychrotrophs have received increased attention by investigators during recent years, because modern developments in the handling and transportation of milk have resulted in milk being held for longer period at refrigeration temperature before processing, manufacturing or consumption (Olfa et al., 2013). 
Psychotropic pseudomonas is recognized as major spoilage microorganisms based on their extracellular thermo-tolerant lipolytic and proteolytic enzymes. The enzymes are generally good indicator of the keeping quality of protein and lipid-rich foods (Cousin et al., 2001).

During the storage of raw milk this enzymes reduce both the quality and shelf life of processed milk (Dogan and Boor, 2003). Although pasteurization of milk has been practiced as the most effective method of reducing the risk of contamination and spreading of disease, many of these enzymes can survive pasteurization $\left(72^{\circ} \mathrm{C}\right.$ for $\left.15 \mathrm{~s}\right)$ and even ultra-hightemperature treatments $\left(138^{\circ} \mathrm{C}\right.$ for $2 \mathrm{~s}$ or $149^{\circ} \mathrm{C}$ for $10 \mathrm{~s}$ ) and can thus reduce the sensory quality and shelf life of processed fluid milk products (Arslan et al., 2001). Second, post pasteurization contamination contributes most of the microorganisms, primarily Pseudomonas spp., that cause spoilage of conventionally pasteurized milk during refrigerated storage (Laura and Mauro 2007).

Although microbial spoilage may merely lead to foodstuffs being rendered unpalatable, it can also result in serious and even fatal illness (Hogg, 2005) Pseudomonas aeruginosa is pathogenic for humans and animals, often as a secondary infection It is now recognized as a common source of many community acquired and nosocomial infections, and affects primarily immunocompromised people and those suffering from cystic fibrosis. The most common infections involve the cornea giving rise to a blue green pus, skin, urinary tract, brain and respiratory tract (Corona et al., 2001).

Infections caused by $P$. aeruginosa are particularly problematic because many aerobic pseudomonades are resistant to several antibacterial agents (Moore et al., 2006). This subject is of particular medical importance because members of this group, such as $P$. aeruginosa, are serious opportunistic human pathogens (Yahr and Parsek, 2006).

The effective antimicrobial agents for the treatment of $P$. aeruginosa infections include some $\beta$-lactams, such as carbenicillin, ticarcillin, third-generation cephalosporins, the synthetic monocyclic $\beta$ - lactam aztreonam, carbapenems, the aminoglycosides, and the quinolones. Pseudomonas aeruginosa and other fluorescent Pseudomonas species are in general resistant to $\beta$-lactams (Garrity et al., 2006). For this reason, current legislation in several countries demands that bottled water products test free of $P$. aeruginosa (Morais et al., 1997). The lack of robust identification tools for these organisms can lead to the misidentification of non-pathogenic Pseudomonas spp. as species; potentially forcing costly and unnecessary food product recalls (Delphine et al., 2008).
Various phenotypic and molecular methods have been developed and used for sub typing bacterial isolates. Phenotypic sub typing methods as biochemical characterization (biotyping), Molecular sub typing methods as polymerase chain reaction (PCR).

The current study was designed to investigate the following points:

1. Isolation and identification of Pseudomonas aeruginosa in raw and pasterulized milk.

2. Serological identification of isolated Pseudomonas aeruginosa strains

3. Characterization of identified stain by pathogenicity test and antibiotic sensitivity test.

4. Molecular Characterization of identified stain by PCR.

\section{MATERIALS and METHODS}

\section{1- Sampling:}

A total of 200 samples of raw and pasteurized milk (100 of each) were collected from some super markets in Qaluobia Governorate. Each sample was collected in sterial bags to minimize the possibility of contamination and send to laboratory with minimum of delay.

\section{2- Isolation of P.aeruginosa:}

According to I. C.M.S.F"1998 one ml from each sample was plated in duplicate using Pseudomonas agar base with $0.1 \%$ cetramide, nutrient agar and MacConkey agar and incubated at $37^{\circ} \mathrm{C}$ for $24-48 \mathrm{~h}$. under aseptic condition.

\section{3- Identification of P.aeruginosa:}

The suspected colonies were purified and identified biochemically according to Quinn et al. (2002).

\section{4- Serological identification: Seiken Co .Ltd, Tokyo, Japan. \\ 5- Detection of P.aeruginosa enzymes: A-Detection of haemolysin:}

$P$. aeruginosa isolated were serogrouped according to Homma (1982) using antisera obtained from Denka

According to Dennis et al. (1980), the isolates were streaked onto blood agar plates and incubated at $37^{\circ} \mathrm{C}$ for 24 hours. Haemolysis was determined by existence of clear zone around the colony.

\section{B- Detection of phospholipase C (lecithinase):}

According to Vanderzant and Splittstoesser (1992), P.aeruginosa isolates were inoculated on the surface of egg yolk agar medium and incubated at $37^{\circ} \mathrm{C}$ for 24-48 hours. Positive result was indicated by appearance of colonies surrounded by zone of opacity. 


\section{C- Detection of caseinase:}

According to (Cappuccino and Sherman, 1999), P.aeruginosa isolates were inoculated on the surface of milk agar medium and incubated at $37^{\circ} \mathrm{C}$ for 24 hours. Positive result was indicated by zone of clearing beneath and around the growth due to clear and cut reactions developing in 24-48 hours.

\section{D- Detection of gelatinase:}

According to (Vanderzant and Splittstoesser 1992) nutrient gelatin tube was stabbed with P.aeruginosa culture and incubated at $37^{\circ} \mathrm{C}$ for 7 days; liquefaction was noted at intervals by removing the tube from incubator and holding it at $4^{\circ} \mathrm{C}$ for 30 minutes before reading the result. Positive result was noted if gelatin was still in a liquid form.

\section{5- Pathogenicity in laboratory animals:}

According to (Ibrahim 2009). (mouse lethality test) 168 albino white mice with average weight of about 18-20 g. and aged 28-30 days old were used to investigate the pathogenicity of $20 \mathrm{~K}$ isolates, $22 \mathrm{H}$ isolates and $14 \mathrm{~A}$ isolates of $P$. areuginosa. Three mice were used for examination of each isolates. All mice were examined bacteriologically to ensure their freedom from pathogens. The mice were inoculated I.P.with $0.1 \mathrm{ml}$ of $5 \times 10^{8}$ C.F.U./mouse of the tested isolate. Mice of all isolates of the same serogroup were kept together. Last 3 mice were kept under observation for 7-10days, the numbers of dead mice were recorded and re-isolation of the inoculated isolates was done.

\section{6- Drug susceptibility testing:}

By using disc diffusion standard technique according to National Committee for Clinical Laboratory Standards (2002) using the following (Oxoide) discs: ciprofloxacin (5ug), enrofloxacin (5ug), norfloxacin (5ug), lomefloxacin (5ug) tobromycin (10ug), ceftriaxone (10ug), gentamycin (10ug), streptomycine (10ug), tetracycline (30ug), erythromycine (15ug) (trimethoprim (25ug) doxycen (20ug), nalidixic acid (30ug).

\section{7- Characterization of isolated P.aeruginosa by} polymerase chain reaction $(\mathrm{PCR})$ :

DNA Extraction Genomic DNA was prepared from isolates according to (Liu et al., 2002). Ten ml overnight cultures were prepared in broth media from fresh single colony. Cells were harvested in a centrifuge for $5 \mathrm{~min}$ at $6000 \mathrm{rpm}$. then suspended in $200 \mu \mathrm{l} 1$ xTE buffer (pH8), then $30 \mathrm{mg} / \mathrm{ml}$ lysozyme to the cell Suspensions was added and incubated for 2 hours at $37^{\circ} \mathrm{C}$. After the incubation, $370 \mu \mathrm{l}$, 1x TE (pH 8) containing Proteinase $\mathrm{K}(1 \mathrm{mg} / \mathrm{ml})$ was added for 1 hour then $30 \mu \mathrm{l}, 10 \%$ SDS were added. The samples were then incubated for $1 \mathrm{~h}$ at $37^{\circ} \mathrm{C}$. then phenol Chloroform extraction was performed using one equal volume of phenol /chloroform/isoamyl alcohol (24/24/1) for 30 minutes and then, samples were centrifuged for $5 \mathrm{~min}$ at $6000 \mathrm{rpm}$.then the aqueous phase was transferred into a clean eppendorf tube and the genomic DNA was precipitated by the addition of cold isopropanol (one equal volume) after addition $10 \%$ of the volume by ammonium acetate and. Finally, the pellet was dissolved in TE buffer. The extracted DNA was performed was stored at $-20^{\circ} \mathrm{C}$ until use.

Primer design. Relevant 16S rDNA sequences available in the GenBank database were speciesspecific primers were designed, (Anzai et al., 2000) as in Table (1).

PCR amplification of targeted DNA was carried out in $25-\mu 1$ reaction volumes, each containing $2 \mathrm{mM}$ $\mathrm{MgCl}_{2}, 50 \mathrm{mM}$ Trizma (pH 8.3; Sigma, St. Louis, Mo.), $250 \mu \mathrm{M}$ (each) deoxynucleoside triphosphates (Promega, Madison, Wis.), $0.4 \mu \mathrm{M}$ (each) primer, $1 \mathrm{U}$ of Taq polymerase (Invitrogen, Carlsbad, Calif.), and $2 \mu \mathrm{l}$ of whole-cell bacterial lysate, and adjusted to 25 $\mu \mathrm{l}$ by the addition of high-performance liquid chromatography-grade $\mathrm{H}_{2} \mathrm{O}$. Amplification was carried out in a Rapid Cycler (Idaho Technology Inc., Salt Lake City, Utah) thermocontroller. After an initial denaturization for $2 \mathrm{~min}$ at $95^{\circ} \mathrm{C}, 25$ cycles were completed, each consisting of $20 \mathrm{~s}$ at $94^{\circ} \mathrm{C}, 20 \mathrm{~s}$ at the appropriate annealing temperature (Table 1), and $40 \mathrm{~s}$ at $72^{\circ} \mathrm{C}$. A final extension of $1 \mathrm{~min}$ at $72^{\circ} \mathrm{C}$ was applied. With this program, the total time for amplification of target DNA was approximately 45 min. PCR products amplifications were detected on standard (\# SM0323) Fermentas was used as a marker, and visualized under UV light.

Table 1: Oligonucleotide primers used for amplification of the $P$. aeruginosa $16 \mathrm{~S}$ rDNA-based primer sets.

\begin{tabular}{|c|c|c|c|c|c|}
\hline Primer & Sequence $\left(5^{\prime}-3^{\prime}\right)$ & Target & $\begin{array}{l}\text { Annealing } \\
\text { temp }\left({ }^{\circ} \mathrm{C}\right)\end{array}$ & Location & $\begin{array}{l}\text { Product size } \\
\quad \text { (bp) }\end{array}$ \\
\hline PA-SS-F & GGGGGATCTTCGGACCTCA & \multirow{2}{*}{$\begin{array}{c}\text { P. aeruginosa } \\
16 \mathrm{~s}\end{array}$} & \multirow[t]{2}{*}{58} & $189-206$ & \multirow[t]{2}{*}{956} \\
\hline PA-SS-R & TCCTTAGAGTGCCCACCCG & & & $\begin{array}{l}1124- \\
1144\end{array}$ & \\
\hline
\end{tabular}




\section{RESULTS}

Table 2: The prevalence of P. aeruginosa isolated from milk samples

\begin{tabular}{|c|c|c|c|}
\hline \multirow{2}{*}{ Types of samples } & \multirow{2}{*}{$\begin{array}{c}\text { No of } \\
\text { examined sample }\end{array}$} & \multicolumn{2}{|c|}{ positive sample } \\
\hline & & No & $\%$ \\
\hline Raw milk & 100 & 40 & 40 \\
\hline Pasteurized milk & 100 & 16 & 16 \\
\hline
\end{tabular}

Table 3: Frequency distribuation of Serogrouping of P.aeruginosa isolated from examined samples

\begin{tabular}{ccccc}
\hline Type of sample & No of isolated strain & Serogroupes & No & $\%$ \\
\hline Raw milk & 40 & $\mathrm{~K}$ & 16 & 40 \\
\cline { 3 - 5 } & & $\mathrm{H}$ & 14 & 35 \\
\cline { 3 - 5 } & \multirow{2}{*}{16} & $\mathrm{~A}$ & 10 & 25 \\
\hline Pasteurized milk & & $\mathrm{K}$ & 4 & 25 \\
\cline { 3 - 5 } & & $\mathrm{H}$ & 8 & 50 \\
\hline & & $\mathrm{A}$ & 4 & 25 \\
\hline
\end{tabular}

Table 4: Detection of enzyme of $P$. aeruginosa isolated from pasterilized and raw milk samples

\begin{tabular}{ccccccc}
\hline \multirow{2}{*}{ Enzyme } & \multicolumn{9}{c}{ Serogroupe } \\
\cline { 2 - 7 } & \multicolumn{2}{c}{$\mathrm{K}(20)$} & \multicolumn{2}{c}{$\mathrm{H}(22)$} & \multicolumn{2}{c}{$\mathrm{A}(14)$} \\
\cline { 2 - 7 } & No. & $\%$ & No. & $\%$ & No. & $\%$ \\
\hline Hamemolysine & 12 & 60 & 12 & 54.5 & 6 & 42.8 \\
\hline Phospholipase & 10 & 50 & 10 & 45.5 & 4 & 28.5 \\
\hline Caseinase & 20 & 100 & 22 & 100 & 14 & 100 \\
\hline Gelatinase & 18 & 90 & 18 & 81.8 & 12 & 85.7 \\
\hline
\end{tabular}

Table 5: Pathogenicity test of P.aeruginosa isolated from milk samples

\begin{tabular}{ccccc}
\hline Serogroupes & No.of serogroupes & No.of tested mice & No.of dead mice & $\%$ \\
\hline K & 20 & 60 & 60 & 100 \\
\hline H & 22 & 66 & 66 & 100 \\
\hline A & 14 & 42 & 24 & 57.14 \\
\hline Total & 56 & 168 & 150 & 89.28 \\
\hline
\end{tabular}


$\underline{\text { Assiut Vet. Med. J. Vol. } 59 \text { No. } 139 \text { October } 2013}$

Table 6: Antibiotic sensitivity test of P.aeruginosa isolated from milk samples

\begin{tabular}{|c|c|c|c|c|c|c|c|c|}
\hline \multirow{3}{*}{$\begin{array}{c}\text { Antibiotic } \\
\text { disc }\end{array}$} & \multicolumn{6}{|c|}{ Serogroups } & \multirow{2}{*}{\multicolumn{2}{|c|}{ Total }} \\
\hline & \multicolumn{2}{|c|}{$\mathrm{K}(20$ strains $)$} & \multicolumn{2}{|c|}{$\mathrm{H}(22$ strains $)$} & \multicolumn{2}{|c|}{ A(strains) } & & \\
\hline & No. & $\%$ & No. & $\%$ & No. & $\%$ & No. & $\%$ \\
\hline Ciprofloxacin & 12 & 60 & 16 & 72.72 & 6 & 42.85 & 34 & 60.7 \\
\hline Enrofloxacin & 10 & 50 & 16 & 72.72 & 4 & 28.57 & 30 & 53.6 \\
\hline Norfloxacin & 10 & 50 & 16 & 72.72 & 4 & 28.57 & 30 & 53.6 \\
\hline Lomefloxacin & 10 & 50 & 16 & 72.72 & 4 & 28.57 & 30 & 53.6 \\
\hline Tobromycin & 4 & 20 & 10 & 45.45 & 0 & 00.00 & 14 & 25.0 \\
\hline Gentamycin & 4 & 20 & 8 & 36.36 & 0 & 00.00 & 12 & 21.4 \\
\hline Ceftriaxone & 4 & 20 & 6 & 27.27 & 0 & 00.00 & 10 & 17.9 \\
\hline Streptomycin & 2 & 10 & 4 & 18.18 & 0 & 00.00 & 6 & 10.7 \\
\hline Erythromycine & 0 & 00 & 2 & 9.09 & 0 & 00.00 & 2 & 3.6 \\
\hline Tetracycline & 0 & 00 & 2 & 9.09 & 0 & 00.00 & 2 & 3.6 \\
\hline Trimethoprim, & 0 & 00 & 0 & 0.00 & 0 & 00.00 & 0 & 0.0 \\
\hline Naldixic acid & 0 & 00 & 0 & 0.00 & 0 & 00.00 & 0 & 0.0 \\
\hline Doxycen & 0 & 00 & 0 & 0.00 & 0 & 00.00 & 0 & 0.0 \\
\hline
\end{tabular}

PCR results:

\section{6s rRNA sequencing}

16S rRNA analysis was performed on all the P.aeruginosa isolates, initially using species-specific oligonucleotide primers designed by (Spilker et al., 2004). The primer set, based on P.aeruginosa conserved regions of the 16s rRNA and designed for the differentiation of P.aeruginosa from other Pseudomonas species, PCR amplification products of $956 \mathrm{bp}$ were obtained for the $P$. aeruginosa isolates compare with control positive (native organ AHRI serology unit) as

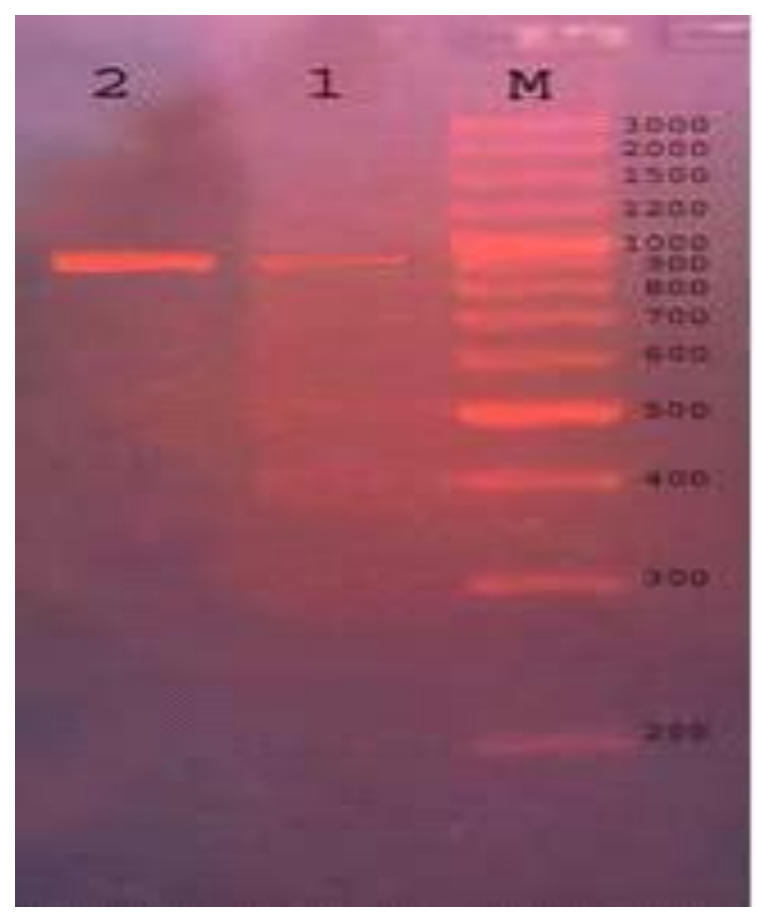

Fig (1): Agarose gel electrophoresis $1 \%$ at 80 Volt /cm of whole genomic DNA of $P$. aeruginosa isolates Lane 1: $P$ aregunosa appeared at $956 \mathrm{bp}$ fragment, lane 2 the positive samples (native organ AHRI Serology Unit) and M: marker 100 bp standard (\#SM0323) Fermentas. 


\section{DISCUSSION}

Contamination of dairy product with Pseudomonas microorganisms is of a particular concern for the dairy industry as dairy products are distributed at temperatures permissive for the growth of these organisms (Ray, 2004).

Psychotropic bacteria typically enter processed dairy products through post pasteurization contamination in the milk processing plant (Khan et al., 2008). Bacterial spoilage ensues when growth conditions during refrigerated storage allow psychotrophic microbes to increase in number and to become the dominant microflora (Dogan and Boor, 2003).

It was evident from Table (2) that the P.aeruginosa was recovered from raw and pasteurized milk with an incidence of $40 \%$ and $16 \%$, respectively. Nearly similar results were reported by Delphine et al. (2008); Laura and Mauro (2007) and Parkash et al. (2007).

To produce the best quality milk and to achieve all the nutritious benefits of it, the highest quality raw milk must be obtained. The conditions of heat treatment used for pasteurization depend on the final product; lower temperatures are used for refrigerated products and higher heat treatments are used for products stored at room temperature (United States Code of Federal Regulation [USCFR], 2006.

In Table (3) Pseudomonas aeruginosa isolated from milk samples belonged to 3 serogroups $\mathrm{K}, \mathrm{H}$, A. The predominant serogroupe was $\mathrm{H}$ (22 isolates) followed by $\mathrm{K}$ ( 20 isolates) then A (14 isolates), nearly similar results was recorded by Laura and Mauro (2007).

Most of P.aeruginosa infections are both invasive and toxigenic as it produce variety of structure and products including outer membrane protein, pilli, enzymes and toxins, which are considered as a major cause of its virulence (Ibrahim, 2009).

In Table (4) there were significant differences among virulence markers of $P$. aeruginosa in relation to their serogroupes. Serogroupe $\mathrm{K}$ was highly virulent followed by $\mathrm{H}$ then $\mathrm{A}$.

Serogroupe K produce Hameolysine, Phospholipase, Caseinase and Gelatinase in percent of 60, 50,100 and 90 , respectively, while serogroupe $H$ produce it in percent of 54.5, 45.5, 100 and 81.8, respectively, in the same while serogroupe A produce it in the percent 42.8, 28.5, 100 and 85.7, respectively, Nearly similar results were reported by Braun and Fehlhaber, (2002) and Geetha and Prasad (2001). Extracellular enzymes (mainly lipases and proteases) that are secreted by these organisms are known to cause spoilage of milk and dairy products, leading to important economic losses (De Jonghe et al., 2010). Lipases degrade the milk fat, causing rancid, soapy, and occasional bitter off-flavors through the formation of medium-chain fatty acids. Proteases that degrade casein cause a gray color, bitter off-flavors, and gelation of ultra hightemperature (UHT) products (Datta and Deeth, 2001). Psychrotolerant bacteria have become more important for the shelf life of heat-treated dairy products because of the development of these bacteria during prolonged refrigerated storage of raw milk on the farm and at the dairy plant. In an effort to reduce the total aerobic plate count of raw milk, a lower storage temperature $\left(1\right.$ to $\left.4^{\circ} \mathrm{C}\right)$ is upheld; leading to the perception that raw milk could be stored for a longer period before further processing. However, the combination of a longer storage time and a lower temperature creates a selective advantage for psychrotolerant bacteria, especially Pseudomonas members that enter raw milk via biofilms in the milk tanks, contaminated water, and soil (Simões et al., 2009). These pseudomonads are able to outgrow other bacteria, such as members of the Aeromonas, Listeria, Staphylococcus, and Enterococcus genera and the family Enterobacteriaceae, thus becoming the predominant microbes in raw milk (Lafarge et al., 2004), constituting up to 70 to $90 \%$ of the psychrotrophic raw milk microbes (Coorevits et al., 2008). Even though they are easily inactivated through pasteurization or UHT treatment, their heatresistant enzymes persist upon processing of the milk (Chen et al., 2003).

In Table 5, Pathogenicity test of P.aeruginosa revealed that $\mathrm{K}$ and $\mathrm{H}$ strains gave $100 \%$ mortalities in mice, while strain A gave lower mortalities $57.14 \%$. (Ibrahim, 2009) isolated the same strains and found nearly the same result of pathogeniciy in mice.

In Table 6, P.aeruginosa varied in their resistance to different antibacterial agents, ciprofloxacin was the most effective drug against P.aeruginosa (60.7\%), followed by enrofloxacin, norfloxacin and lomefloxacin (53.6\%). P.aeruginosa was low in susceptibility to tobromycin $(25.0 \%)$, gentamycin (21.4\%) ceftriaxone (17.9\%) streptomycin (10.7\%) erythromycin (3.6\%) tetracycline (3.6\%). The bacterium was completely resistant to trimethoprim, naldixic acid and doxycen. Similar results were recorded by Arslan et al. (2011), while Amany et al. (2006) and Crespo et al. (2004) found that P.aeruginosa isolated from some clinical and environmental samples was sensitive to gentamicin and ciprofloxacin, this might be due variation in the usage of antibiotics in different geographical areas. P.aeruginosa is a clinically significant pathogen characterized by intrinsic resistance to number of antimicrobial agents, moreover problem with the development of resistance to agent generally exhibiting potent antibacterial activity against this organism are encountered with increasing frequency 
and cross resistance to chemically unrelated antibiotics (Muramatsu et al., 2005).

Two primer pairs were used in this study; the pair PA16S-F and PA16S-R which was specific to $P$. aeruginosa. These primers targeted the variable regions in the $16 \mathrm{~S}$ rRNA gene. PCR assays employing this primer pair produced DNA products of the predicted size (Figure: 1). 16S rRNA gene sequence offered a useful method for the identification of bacteria. It had long been used as a taxonomic method in determining the phylogenies of bacterial species (Drancourt et al., 2000). Genomic DNA This results agree with Khulod et al. (2012) and Theodore et al. (2004) they recorded the band at 956 bp.16s rRNA sequencing is therefore now considered to be the hierarchy in phenotypic identification (Woese, 1987). So 16s rRNA sequencing was performed on all the "P.aeruginosa" isolates for definitive identification, as shown. 16s rRNA genes are conserved among all organisms however possess various unique species regions that allow bacterial identification (Gobel et al., 1987). However, the advancement in 16s rRNA analysis has resulted in the development of rapid diagnostic techniques for the identification of P.aeruginosa (O'Callaghan et al., 1994; LiPuma et al., 1999; Spilker et al., 2004).

PCR used this method in genotypic characterization of Pseudomonas strains isolated from bulk tank milk and act as a rapid and accurate method for typing Pseudomonas spp (Wang and Jayarao, 2001).

In this study, the presence of Pseudomonas aeruginosa after pasteurization may be due to insufficient pasteurization or the post contamination by this genus and the temperature which milk and dairy products are exposed influences the type of microorganisms that will grow in them.

As dairy equipment and utensils constitute the major source of many types of psychrotrophics in milk, so special attention should be considered in their cleaning and sanitation to produce milk of low bacterial count or even completely free of psychrotrophics bacteria. The previous information indicated that psychrotrophics are still inevitable because they are widely distributed in nature, withstand sanitizers and can liberate heat stable enzyme causing spoilage of food and some of them considered as food borne pathogens. This knowledge increase attention toward the way by which the restriction of these microorganisms must be done, we can concluded also that PCR act as a rapid and accurate method for typing Pseudomonas spp.

\section{REFERENCES}

Amany, I.E.; Ebtehal, A.E. and Osman, A.O. (2006): Plasmid mediated carbapenems resistance in clinical and environmental isolates of
Pseudomonas aeruginosa recovered from sheep farm.S.C.V.M.J. X (1)7-16.

Anzai, Y.; Kim, H.; Park, J.-Y.; Wakabayashi, H. and Oyaizu, H. (2000): Phylogenetic affiliation of the pseudomonads based on 16S rRNA sequence. Int. J. Syst. Evol. Microbiol. 50: 1563-1589.

Arslan, S.; Eyi, A. and Özdemir, F. (2011): Spoilage potentials and antimicrobial resistance of Pseudomonas spp. isolated from cheeses. Dairy Sci. 94: 5851-5856

Aysel, U.; Özgür, C. and Belma, A. (2012): Characterization of Pseudomonas spp. from seawater of the southwest coast of Turkey. J. Biol. Environ. Sci., 6(16), 15-23.

Braun, P. and Fehlhaber, K. (2002): Combined effect of temperature, a and $\mathrm{pH}$ on enzymatic activity of spoilage causing bacteria. Milchwissenschaft, 57: 134-13

Cappuccino, J.G. and Sherman, N. (1999): Microbiology: A laboratory manual Benjamin/Cummings Publ. Company, New York pp: 477.

Chen, L.; Daniel, R.M. and Coolbear, T. (2003): Detection and impact of protease and lipase activities in milk and milk powders. Int. Dairy J. 13: 255-275.

Coorevits, A.; De Jonghe, V.; Vandroemme, J.; Reekmans, R.; Heyman,; Messens, W.; De Vos, P. and Heyndrickx, M. (2008): Comparative analysis of the diversity of aerobic spore-forming bacteria in raw milk from organic and conventional dairy farms. Syst. Appl. Microbiol. 31: 126-140.

Corona, N.A.L.; Miranda, N.M.G.; Leanos, M.B.; Portillo, G.L.; Heranandez, C.a.; Anthor, R.J. and Aguilar, B.S. (2001): Epidemiologic study of Pseudomonas aeruginosa in critical patients and reservoirs Arch. Med. Res. 32(3): 238-242.

Cousin, M.A.; Jay, J.M. and Vasavada, P.C. (2001): Psychotrophic microorganisms. In Compendium of Methods for the Microbiological Examination of Foods. F. P. Downes and K. Ito, K, Ed. A.P. H. A., Washington, DC. 159-166.

Crespo, M.P.; Woodford, N.; Sinclair, A.; Kaufmann, M.E.; Turton, J.; Glover, J.; Velez, J.D.; Castaneda, C.R.; Recalde, M. and Livermore, D.M. (2004): Outbreak of Carbapenem-Resistant Pseudomonas aeruginosa Producing VIM-8, a Novel Metallo- $\beta$-Lactamase, in a Tertiary Care Center in Cali, Colombia J. Clin. Microbiol.; 42(11): 5094-5101.

Datta, N. and Deeth, H.C. (2001): Age gelation of UHT-milk-a review. Food Bioprod Process. 79: 197-210. 
De Jonghe, V.; Coorvits, A.; De Block, J.; Van Coillie, E.; Grijspeerdt.; Herman, L.; De Vos, P. and Heyndrickx (2010): Toxinogenic and spoilage potential of aerobic sporeformers isolated from raw milk. Int. J. Food Microbiol. 136: 318-325.

Delphine, D.; Muriel, N.; Clarisse, P.; Alain, D.; Emilie, B.; Gerard, H. and Jean-Lue, G. (2008): Molecular typing of industrial strains of Pseudomonas spp. isolated from milk and genetical and biochemical characterization of an extracellular protease produced by one of them. Inter.J. F. Microbiol., 125; 2: 188-196

Dennis, E.O.; Jeraldand, C.S. and Barbara, H.I. (1980): Toxin A deficient mutants of P.aeruginosa PA103: Isolation and characterization. Infect. Immun. 899-908.

Dogan, B. and Boor, K.J. (2003): Genetic diversity and spoilage potentials among Pseudomonas from fluid milk products and dairy processing plants .Appl. Environ. Microbiol. 69: 130-138.

Drancourt, M.; Bollet, C.; Carlioz, A.; Martelin, R.; Gayral, J.-P and Raoult, D. (2000): 16S ribosomal DNA sequence analysis of a large collection of environmental and clinical unidentifiable bacterial isolates. J. Clin. Microbiol. 38: 3623-3630.

Garedew, L.; Berhanu, A.; Mengesha, D. and tesgay, $G$. (2012): dentification of gram-negative bacteria from critical control points of raw and pasteurized cow milk consumed at Gondar town and its suburbs, Ethiopia. BMC Public Health. 6; 12:950

Garrity, G.M.; Bell, J.A. and Lilburn, T. (2006): Order IX. Pseudomonadales. In Bergey's Manual of Systematic Bacteriology. D.J. Brenner, N.R. Krieg, and G.M. Garrity, ed. Springer, New York, NY. 2: 323-373

Geetha, R. and Prasad, V. (2001): Studies on the performance of cultures on lactic acid bacteria in lactose hydrolysed buffalo skim milk. Cheiron, 30: 81-84.

Gobel, U.B.; Geiser, A. and Stanbridge, E.J. (1987): "Oligonucleotide probescomplementary to variable regions of ribosomal RNA discriminate between Mycoplasma species." Journal of General Microbiology 133(7): 1969-1971.

Hogg, S. (2005): Essential Microbiology (Microorganisms in Industry). John Wiley and Sons, West Sussex, UK.

Homma, J.Y. (1982): Designation of the thirteen Ogroup antigens of Pseudomonas aeruginosa; an amendment for the tentative proposal in 1976. Jpn J Exp Med 52: 317-320.

Ibrahim, Hala, S. (2009): The prevalence and characterization of Pseudomonas aeruginosa isolated from ostriches. Egypt. J., of Appl. Sci. 24(6A) 14-31.

International Commission on Microbiological Specification for Foods. "I. C.M.S.F" (1998): Microorganism in food 3 sampling for microbiological analysis. Principle and Specific Application of Toronto Press, Toronto, Ontario, Canada.

Khan, M.T.; Zinnah, M.A.; Siddique, M.P.; Rashid, M.H.; Islam, M.A. and Choudhury, KA. (2008): Physical and Microbial Qualities of Raw milk Collected from Bangladesh Agricultural University, Dairy Farm and the Surrounding Villages. Bangl J. Vet. Med.; 6: 217-221.

Khulod, I. Hassan; Saman, A. Rafik and Khider, M. (2012): Molecular identification of Pseudomonas aeruginosa isolated from Hospitals in Kurdistan region. Journal of Advanced Medical Research. 2.3, 90-98.

Lafarge, V.; Ogier, J.C.; Girard, V.; Maladen, V.; Leveau, J.Y.; Gruss, A. and DelacroixBuchet. A. (2004): Raw cow milk bacterial population shifts attributable to refrigeration. Appl. Environ. Microbiol. 70: 5644-5650.

Laura, F. and Mauro, S. (2007): Characterization of Pseudomonas spp. isolated from foods. Annals of Microbiology, 57 (1) 39-47

Lendenbach, L.H. and Marshal, R.T. (2009): Microbiological Spoilage of Dairy Products, Compendium of the Microbiology Spoilage of Foods and Beverages, Food Microbiology and Food Safety. USA: Springer Science and Business media. 87-89.

LiPuma, J.J.; Dulaney, B.J.; McMenamin, J.D.; Whitby, P.W.; Stull, T.L.; Coenye, T. and Vandamme, P. (1999): "Development of rRNA-Based PCR Assays for Identification of Burkholderia cepacia Complex Isolates Recovered from Cystic Fibrosis Patients." J. Clin. Microbiol. 37(10): 3167-3170.

Liu, L.; Coenye, T.; Burns, J.L.; Whitby, P.W.; Stull, T.L. and LiPuma, J.J. (2002): Ribosomal DNA-directed PCR for identification of Achromobacter (Alcaligenes) xylosoxidans recovered from sputum samples from cystic fibrosis patients. J. Clin. Microbiol. 40: 1210-1213.

Moore, E.R.B.; Tindall, B.J.; Dos Santos, V.A.P.M.; Pieper, D.H.; Ramos, J. and Palleroni, N.J. (2006): Nonmedical: Pseudomonas.in The Prokaryotes. M. Dworkin, S. Falkow, E. Rosenberg, K.H. Schleifer, and E. Stackebrandt, ed. Springer, New York, NY. 6: 646-703

Morais, P.V.; Mesquita, C.; Andrade, J.L. and da Costa, M.S. (1997): Investigation of persistent colonization by Pseudomonas aeruginosa -like strains in a spring water 
bottling plant. Appl. Environ. Microbiol. 63: 851-85.

Muramatsu, H.; Horii, T.; Takeshita, A.; Hushinoto, H. and Maekawa, M. (2005): Characterization of fluoroquniolone and carbapenem susceptibilities in clinical isolates of level floxacin resistance P.aeruginosa. Chemotheraphy, 51(2-3): 70-75.

National Committee for Clinical Laboratory (NCCLS) (2002): M-100Documentes performance standards for antimicrobial suscepetibility. Testing 21:1.

O'Callaghan, E.M.; Tanner, M.S. and Boulnois, G.J. (1994): "Development of a PCR probe test for identifying Pseudomonas aeruginosa and Pseudomonas (Burkholderia) cepacia." Journal of Clinical Pathology 47: 222-224.

Olfa, S.B.; Imène, F.; Rouaa, L.; Hamadi, A. and Mohamed, A.A. (2013): Study of Proteolytic and Lipolytic Activities of Pseudomonas spp. Isolated From Pasteurized Milk in Tunisia Journal of Agricultural Science; Vol. 5, No. 7; 2013.

Parkash, M.; Rajasekar, K. and Karmegam, N. (2007): Bacterial population of raw milk and their proteolytic and lipolytic activities. Res. J. Ba. App. Sci. 3(6): 848-851.

Quinn, P.J.; Markey, B.K.; Carter, M.E.; Donnelly, W.J.C.; Leonard, F.C. and Maguire, D. (2002): Veterinary microbiology and microbial disease. Published, Blackwell Science Ltd.

Ray, B. (2004): Fundamental Food Microbiology. C.R.C. Press, Boca Ra-ton, FL.

Simões, M.; Simões, L.C. and Vieira, M.J. (2009): Species association increases biofilm resistance to chemical and mechanical treatments. Water Res. 43: 229-237.

Singh, P.; Wani, A.A; Karim, A.A. and Langowski, A.A. (2012): The use of carbon dioxide in the processing and packaging of milk and dairy products: A review. International Journal of Dairy Technology, 65, 161-177.

Spilker, T.; Coenye, T.; Vandamme, P. and LiPuma, J.J. (2004): "PCR-based assay for differentiation of Pseudomonas aeruginosa from other Pseudomonas species recovered from cystic fibrosis patients." Journal of Clinical Microbiology 42(5): 2074-2079.

Theodore, S.; Tom, C.; Peter, V. and John J. LiPuma (2004): PCR-Based Assay for Differentiation of Pseudomonas aeruginosa from Other Pseudomonas Species Recovered from Cystic Fibrosis Patients. Clin. Microbiol. 42. 5 2074-2079.

United States Code of Federal Regulation (2006): How heat treatment affect the final product. C.F.R. Title 21, part 131, Section 112.

Vanderzant, C. and Splittstoesser, D.F. (1992): Compendium of methods for the microbiological examination of foods. Washington, D.C.: American Public Health Association.

Wang, L. and Jayarao, BM. (2001): Phenotypic and genotypic characterization of Pseudomonas fluorescens isolated from bulk tank milk. J. Dairy Sci., 84: 1421-1429.

Wiedmann, M.; Weilmeier, D.; Dineen, S.S.; Ralyea, R.M.; Boor, K.J. (2000): Molecular and Phenotypic characterization of Pseudomonasspp. isolated from milk. Appl. Environ. Microbiol. 66 (5): 2085-2095.

Woese, C.R. (1987): "Bacterial evolution." Microbiol Rev. 51(2): 221-71.

Yahr, T.L. and Parsek, M.R. (2006): Pseudomonas aeruginosa. in The Prokaryotes. M. Dworkin, S. Falkow, E. Rosenberg, K. H. Schleifer, and E. Stackebrandt, ed. Springer, New York, NY. 6: 704-713.

\section{تحديد الخصائص الجزيئيه لميكروب السيدومونس اريجينوزا المززول من اللبن \\ نهله /حد ابو الروس ، ابتسام محد مزيل ، ايمان مجلى زخاري ، خيزى فاروق ابو اليزيا \\ Email: (imanmagdy@yahoo.com)}

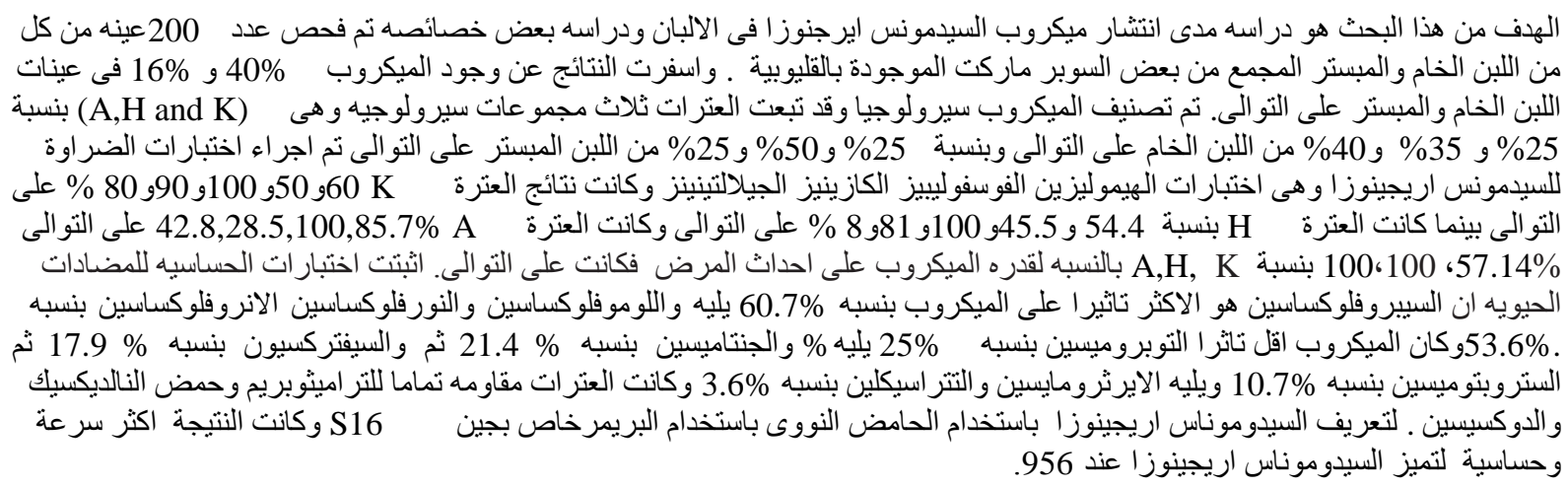

